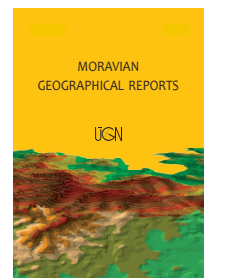

MORAVIAN GEOGRAPHICAL REPORTS

\title{
Effects of light pollution on tree phenology in the urban environment
}

\author{
Jana ŠKVARENINOVÁ a , Mária TUHÁRSKA a , Jaroslav ŠKVARENINA a *, Darina BABÁLOVÁ a , \\ Lenka SLOBODNÍKOVÁ a , Branko SLOBODNÍK ${ }^{a}$, Hana STŘEDOVÁ ${ }^{b}$, Jozef MINĎAŠ c
}

\begin{abstract}
Research on urban climates has been an important topic in recent years, given the growing number of city inhabitants and significant influences of climate on health. Nevertheless, far less research has focused on the impacts of light pollution, not only on humans, but also on plants and animals in the landscape. This paper reports a study measuring the intensity of light pollution and its impact on the autumn phenological phases of tree species in the town of Zvolen (Slovakia). The research was carried out at two housing estates and in the central part of the town in the period 2013-2016. The intensity of ambient nocturnal light at 18 measurement points was greater under cloudy weather than in clear weather conditions. Comparison with the ecological standard for Slovakia showed that average night light values in the town centre and in the housing estate with an older type of public lighting, exceeded the threshold value by 5 lux. Two tree species, sycamore maple (Acer pseudoplatanus L.) and staghorn sumac (Rhus typhina L.), demonstrated sensitivity to light pollution. The average onset of the autumn phenophases in the crown parts situated next to the light sources was delayed by 13 to 22 days, and their duration was prolonged by 6 to 9 days. There are three major results: (i) the effects of light pollution on organisms in the urban environment are documented; (ii) the results provide support for a theoretical and practical basis for better urban planning policies to mitigate light pollution effects on organisms; and (iii) some limits of the use of plant phenology as a bioindicator of climate change are presented.
\end{abstract}

Keywords: intensity of illumination, phenology, sycamore maple (Acer pseudoplatanus L.), staghorn sumac (Rhus typhina L.), urban climates, bioindicators, Zvolen, Slovakia

Article history: Received 20 February 2017; Accepted 28 November 2017; Published 31 December 2017

\section{Introduction and theoretical departures}

The environment affects the complete set of physiological and psychological reactions of living organisms. Their everyday life is threatened by pollution of the basic components of the environment, i.e. soil, water and air (Hreško et al., 2015). Humans with demands for intensive night lighting disturb the environment and influence the biorhythms of living organisms. Increasing attention has been paid to this issue since the 1970 s as a reaction to increasing urbanisation (see e.g. Riegel, 1973; White, 1974; Verheijen, 1985). New questions about light pollution have been posed, together with effective and efficient solutions, which are dealt by experts in the fields of psychology, architecture, construction, engineering and environmental hygiene. According to Gaston et al. (2013), future research will focus on the determination of threshold values beyond which light pollution has negative ecological impacts on the composition and trophic structures of ecosystems and species growing in an urban environment.

Worldwide artificial lighting is rapidly increasing by around $2.2 \%$ per year (Kyba et al., 2017). Bennie et al. (2014) showed that regionally significant decreases, as well as widespread increases, in the brightness of night time lights are occurring across Europe. In the Slovak Republic, the data show widespread decreases in observed brightness across small towns and villages, as many municipalities began switching off public lighting for part or all of the night for financial reasons during this period. The capital, Bratislava, and several towns that experienced renovation of their lighting systems do not show an equivalent decrease. Following the regulation of the European Commission (ES No. 245/2009), the term "pollution" is generally understood

\footnotetext{
a Technical University in Zvolen, Slovak Republic (*corresponding author: J. Škvarenina; e-mail: skvarenina@tuzvo.sk)

${ }^{\mathrm{b}}$ Mendel University in Brno, Faculty of AgriSciences, Brno, Czech Republic

${ }^{\mathrm{c}}$ University of Central Europe in Skalica, Slovak Republic
} 
as a contamination of the environment by artificial lighting sources with negative impacts on the environment (Official Book of the European Union, 2009). Light influences several natural processes, and has a significant impact on the biological and ecological processes of many species (Rich and Longcore, 2006; Solano and Kocifaj, 2013). The International Dark-Sky Association (IDA) defines light pollution as: "any undesirable impact of artificial lighting causing excessive sky brightness, radiance, infiltration of excessive light into houses, reduced visibility on roads and wasteful energy consumption" (IDA, 2013). Light pollution can be best observed in towns and large residential agglomerations. Light directed towards the sky is reflected from atmospheric particles (dust, water vapour) and is spread far beyond the place of its origin. It results in a visibly clearer sky at night even at a greater distance from the source, especially in populated areas.

Excessive artificial light added to the nocturnal landscape is a serious ecological burden on the environment, with adverse impacts on the biorhythms of living organisms (Longcore and Rich, 2004). Natural darkness is needed for living organisms that are active during a day, and also for humans to have rest and to ensure the correct course of their circadian rhythms. Excessive light is a problem for animals with increased night activity. The lack of darkness disrupts their natural life cycle, which they have become adapted to over millions of years during evolution. Birds living in towns have problems to recognise that night is approaching. Light pollution alters the phenology of dawn and dusk singing of the songbirds (Da Silva et al., 2015), which begin to nest at the wrong time, and to move to non-native habitats. Flying through over-illuminated zones causes their disorientation and frequent collisions with obstructions such as towers and buildings (Rich and Longcore, 2006).

Plant growth and development are influenced by light spectral quality, quantity and duration. The plant photoreceptors - phytochromes, cryptochromes, phototropins and FkF1 photoreceptor-mediate physiological and developmental responses in plants (Briggs, 2006). The phytochrome is blue-green plant pigment which regulates plant development, seed germination, flowering and leaf expansion. The phytochrome system allows plants to grow towards light. Sometimes photoreceptors act independently, sometimes redundantly, sometimes cooperatively, sometimes antagonistically, sometimes at the same stage of development, and sometimes at different stages of development. Moreover, some of these responses are incredibly sensitive (Briggs, 2006).

Some plants and tree species also react to strong light sources and to changes in the day/night length. Approximately $80 \%$ of flowering plants are sensitive to photo-periodism (Samach and Gover, 2001; Searle and Coupland, 2004). Naturally, their blossom, bud-burst and leaf fall occur in appropriate seasons. Within less than 10 minutes after changing the radiation intensity, the plant reacts by altering its transpiration (Klimešová and Středa, 2016). The change in photoperiod can influence flowering response, as well as their entrance into bud dormancy, or their initiation of leaf senescence. Artificial light in the night-time environment is sufficiently bright to induce a physiological response in plants, affecting their phenology, growth form and resource allocation (Briggs, 2006; Bennie et al., 2016) In temperate zones, many woody plants normally undergo a flush of vegetative growth induced by some environmental change, such as an increase in temperature or the onset of a rainy season. In due time, however, the buds stop producing normal leaves and commence instead to produce bud scales. Ultimately, the buds cease producing any new organs and enter complete dormancy. Seedlings on long days continue growing far longer than seedlings on short days before the buds go into dormancy. Hence, artificially extending the day length can significantly increase the length of time during which active growth and production of true leaves takes place (Briggs, 2006).

Artificial red light changes phenology and research results show that artificial yellow lighting has a similar impact (Cathey and Campbell, 1975). The leaf stomata of some tree species are open at night and closed during the day to protect plants from wilting, which would occur during the day. Trees growing near artificial lights react to autumn cooling and low temperatures with a delay. Their leaves do not change their colour, but often freeze fully green. Ice and snow, which is captured on their surface, can cause breaking of branches. Maples, birches, poplars and sycamores are sensitive to night light (Chaney, 2002).

Johnston et al. (1969) found that brightly illuminated plants under a wide spectrum fluorescent lamps had had more seeds, nodes, pods, branches, pods per node, seeds per pod and a higher oil content, than normal plants. Protein content and seed size were decreased by adding light. Okamoto et al. (1997) and Lee et al. (2010) showed accelerating grown of lettuce seedlings under fluorescent light. Phenological monitoring can detect several types of changes occurring in the natural environment, such as toxic emissions in the air or climate change, which has been examined in the study region by a number of authors (e.g. Bednářová et al., 2013; Hájková et al., 2012; Chuchma et al., 2016; Stehnová and Středová, 2016). The impact of light pollution on phenological phases of plants has been studied to a much lesser extent.

This paper deals with the monitoring of light pollution intensity in the urbanised parts of the town of Zvolen, situated in Central Slovakia. The research project aims to assess the effect of light pollution on the autumn phenological phases of selected tree species in urban conditions.

\section{Material and methods}

The measurements of light pollution intensity were carried out in the town of Zvolen in Central Slovakia (Central Europe) from 2013 to 2016. The town is situated at an elevation of $293 \mathrm{~m}$ a.s.l. $\left(48^{\circ} 34^{\prime} 42^{\prime \prime} \mathrm{N}, 19^{\circ} 07^{\prime} 24^{\prime \prime} \mathrm{E}\right)$. It belongs to a warm climatic region, slightly moist sub-region, and is a type of valley climate with frequent temperature inversions and an average annual precipitation total of $703 \mathrm{~mm}$ (Lapin et al., 2002). The average annual air temperature is $8.2{ }^{\circ} \mathrm{C}$ : the coldest month is January with mean temperature of $-3.4{ }^{\circ} \mathrm{C}$, and the warmest month is July with temperature $18.8^{\circ} \mathrm{C}$. The maximum precipitation amount falls in June $(82 \mathrm{~mm})$, with a second maximum of precipitation in November (66 mm; Střelcová, 2013). For a detailed description of the natural conditions of Zvolen and its surroundings: see Belaček and Bebej (2013).

Measurements of light pollution intensity and phenological monitoring of tree species were made at three sites (Fig. 1)

Site 1 (Tepličky) is a relatively new housing estate, which was built at the end of the 1980s on the right bank of the river Hron. To the north, it is adjacent to a shopping 


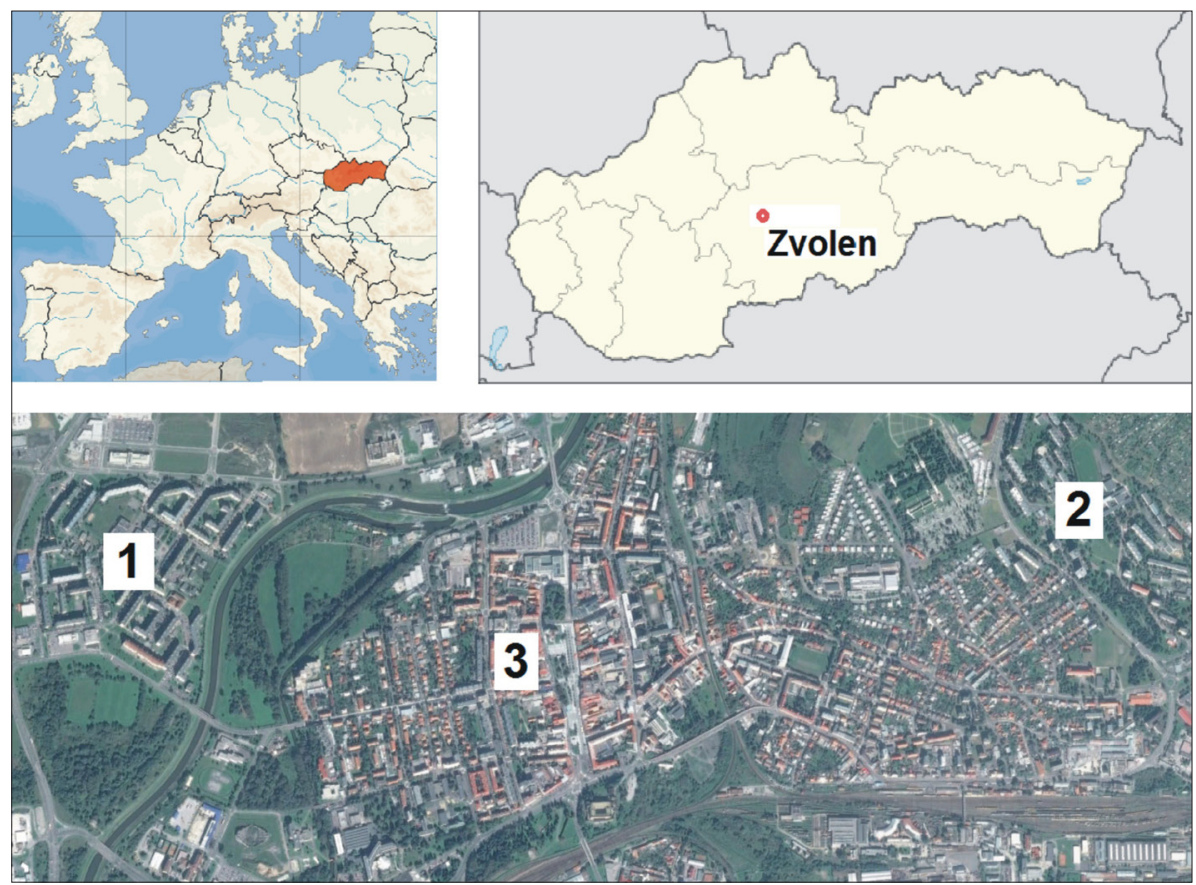

Fig. 1: Location of the research sites in the town of Zvolen, Slovak Republic: 1) Tepličky housing estate; 2) Zlatý potok housing estate, 3) Town centre

Source: authors' elaboration

centre and a small industrial zone. It has a lower night light intensity with more modern lighting. Tree species were planted either individually or in small groups and are 20 to 25 years old on average. Site 2 (Zlatý potok) is an older housing estate from the 1960s and 1970s. It is located in the foothills of the Zvolen highlands in the eastern part of the town. It is adjacent to a commercial and industrial zone which, together with an older type of lighting, causes a higher level of night-time brightness. Trees create smaller park zones and alleys. They are approximately 30 to 40 years old. Site 3 represents the town centre with its historical part, square, transport corridors, bus and railway stations, administrative and commercial buildings. It is the most intensely lit part of the town. The trees are of different ages - from young peripheral plantings (younger than 10 years) up to several old town parks with trees aged more than 80 years. Following the methodology of Effelsen (1991), urban terrain zones (UTZ) were identified according to the criteria of a structure, street pattern, lot configuration, building placement on the lot, building density, building construction type and age of construction. The local climate zones (LCZ) were identified following the methodology of Stewart and Oke (2012) according to local temperature regime and surface cover. The LCZ classification can be used easily and properly as a basic source of information about the nature of the area around a station, and it can be efficiently used for representative documentation of the neighbourhood of the climate stations (Lehnert et al., 2015). Finally, urban climate zones (UCZ) were identified following Oke (2006) see Table 1.

In general, the artificial luminance of the sky in urban environments is being measured by various types of sky quality meters. They measure luminance (surface brightness) for a patch of the sky, in units of magnitudes per square arc second (mag. $\operatorname{arcsec}{ }^{-2}$ ). Nevertheless our measurement dealt with available sensors that measure the light in lux. These units of light pollution are comparable with the valid norm. Light pollution intensity was measured with Lux Meter Velleman DVM 1300 (Company Dertronics B.V. Netherlands) under two different weather conditions (clear and cloudy sky).

The measurements were carried out just under the light sources adjacent to the planted woody plants along pavements or roads. The sensors were placed at the height of $1.3 \mathrm{~m}$ to enable an accurate reading of the data on the lux meter sensor's display. The data therefore do not represent the maximum at the level of treetops regarding their height. Therefore, neither the measurement on lighted and unlighted sides of the treetop were carried out. Only a phenological reaction on a negative factor was recorded.

\begin{tabular}{|c|c|c|c|c|}
\hline Site & GPS location & $\begin{array}{l}\text { Ellefsen (1991) UTZ } \\
\text { classification }\end{array}$ & $\begin{array}{c}\text { Stewart \& Oke (2012) LCZ } \\
\text { classification }\end{array}$ & $\begin{array}{l}\text { Oke }(2006) \text { UCZ } \\
\text { classification }\end{array}$ \\
\hline 1 & $48^{\circ} 34^{\prime} 49^{\prime \prime} \mathrm{N} 19^{\circ} 06^{\prime} 31^{\prime \prime} \mathrm{E}$ & Dc3 & $\begin{array}{l}\text { LCZ 1A (Compact high-rise } \\
\text { with dense trees) }\end{array}$ & UCZ 1 \\
\hline 2 & $48^{\circ} 34^{\prime} 51^{\prime \prime} \mathrm{N} 19^{\circ} 08^{\prime} 48^{\prime \prime E}$ & Dc3 & $\begin{array}{l}\text { LCZ 1A (Compact high-rise } \\
\text { with dense trees) }\end{array}$ & UCZ 1 \\
\hline 3 & $48^{\circ} 34^{\prime} 34^{\prime \prime} \mathrm{N} 19^{\circ} 07^{\prime} 39^{\prime \prime} \mathrm{E}$ & $\mathrm{A} 1$ & $\begin{array}{l}\text { LCZ 3B (compact low-rise with } \\
\text { scattered trees) }\end{array}$ & UCZ 2 \\
\hline
\end{tabular}

Tab. 1: Characteristics of the site's environments Source: authors' elaboration 
The measurement device itself was not equipped with a cosine shield limiting incoming radiation. Thus, the values of artificial luminance of the sky contain also direct and diffuse radiation of the atmosphere. We used the following methodological principles:

i. no obstacles that can cast shadows shall be between the instrument and the sky (a building, or a tree);

ii. the measurements shall not be performed at the places where light sources directly cast shadows; and

iii. the worker performing measurements shall not stand at the place directly lit by the light flux from the source (e.g. under the lamp).

The individual sites were divided into a square grid of $100 \times 100 \mathrm{~m}$ in GIS software (ArcGIS). The measurement points were selected within the grid created in GIS. At each site, we selected 6 measuring points adjacent to light sources of different types and intensity. At each measuring point, we performed 20 partial measurements under every type of weather condition, from which we calculated the arithmetic mean to obtain the final values of light pollution.

The measurements were carried out only after an appropriate warming up and stabilisation of artificial lights and at complete darkness after $10 \mathrm{pm}$ local time. High pressure sodium lamps with spherical diffusers and top covers, and LED lighting with flat diffusers, were used at every site. At site 3 , the town centre, there were also ground lights for the pedestrian zone, which illuminated historical buildings and park greenery. Decree No. 539/2007 Coll. based on STN EN 12464-2 technical standard was adopted in the Slovak Republic in order to protect and enhance the night environment and to control disturbing light (known as light pollution), which can cause physiological and ecological problems in the surrounding environment and for people. An equivalent standard based on the EU Regulation 245/2009 is valid also in the neighbouring country of the Czech Republic. According to the standard, the highest allowed values of disturbing light in the town centres and residential suburbs fluctuate between 2-5 lux depending on the urbanisation type, which corresponds with the conditions in the researched town.

The phenological data were gathered following the methodology of the Slovak hydro-meteorological institute (Kolektív, 1984). We observed the following autumn vegetative phenological phases:

i. leaf colouring $\mathrm{LC}$ (BBCH 92) - leaves change their colour to yellow up to yellow-brown;

ii. leaf fall $\mathrm{LF}$ (BBCH 93) - yellow leaves fall even in still air. The 10, 50 and $100 \%$ occurrence of each phenological phase was observed on both the lit and the unlit parts of tree crowns. We determined the length of the phenophase duration as a difference between $10 \%$ and $100 \%$ onset. As a control sample, we used individuals of the particular species of the observed group or located in an alley beyond the lighting.

\section{Results and discussion}

Changes in the onset of phenophases cannot be caused simply by the urban heat island (i.e. temperature differences between city centre and the outskirts by up to $5{ }^{\circ} \mathrm{C}$ caused by intensive warming of artificial surfaces by incoming solar radiation). Such a possibility has been described and quantified for similar geographic and urban conditions to this study by Pokladníková et al. (2009), Geletič and Vysoudil (2012), Středová et al. (2015) and Vysoudil et al. (2016). Changes of phenology are too large to be explained by increases in temperature alone - the effect of light pollution is evident (French-Constant et al., 2016; Da Silva et al., 2015).

\subsection{Light pollution intensity}

The measurements of light pollution intensity (lux) were performed under different weather conditions. The measured values are presented in Table 2.

We found a difference between the weather conditions and the intensity of light pollution. Under higher air humidity and cloudy sky conditions, the average light intensity of every site was higher (1.8-8.5 lx) than under clear sky conditions (1.1-6.5 lx). This is due to the higher reflectance of light from water drops or aerosols (Tuhárska et al., 2016; Kyba et al., 2011). The same conclusions were stated by Bujalský et al. (2014), who found five-times higher pollution intensity under foggy and cloudy conditions than under clear skies (see also: Kyba et al., 2011). See the note under 'Conclusions' below. The highest average value of light intensity was found at site 3 , the town centre, regardless of the weather conditions - due to the type of lights used and other lighting elements (ground lighting, advertisement panels, etc.). The lowest values were observed at site 1 , which is the most recent housing estate with modern types of lights.

The measured data were compared with the standard (Decree No. 539/2007). Following the standard, sites 1 and 2 in the housing estates belong to an E3 ecological zone - an urbanised area with moderate brightness (housing suburbs of small towns), for which the maximum threshold value is 2 lux. The site of the Zvolen town centre is in the E4 ecological zone with high brightness and a threshold value of 5 lux. The comparison of our values with the standard values showed that the 'best' situation was in the modern and newest housing estate, "Západ" (site 1 - Tepličky), at which the measured average values of light pollution in the years 2013 and 2014 did not exceed the standard threshold values under any studied weather conditions. The situation at this site changed in the years 2015 and 2016, when the threshold was exceeded

\begin{tabular}{|c|c|c|c|c|c|c|c|c|}
\hline \multirow{2}{*}{$\begin{array}{c}\text { Weather conditions } \\
\text { Site/year }\end{array}$} & \multicolumn{4}{|c|}{ Clear sky } & \multicolumn{4}{|c|}{ Cloudy sky } \\
\hline & 2013 & 2014 & 2015 & 2016 & 2013 & 2014 & 2015 & 2016 \\
\hline 1 & 1.1 & 1.2 & 4.2 & 4.8 & 1.8 & 1.9 & 6.7 & 6.2 \\
\hline 2 & 3.1 & 3.3 & 5.7 & 5.2 & 4.1 & 4.6 & 7.8 & 7.1 \\
\hline 3 & 6.0 & 6.3 & 7.1 & 6.5 & 6.4 & 6.6 & 8.5 & 7.9 \\
\hline
\end{tabular}

Tab. 2: Intensity of average values of light pollution in lux $(l x)$ at the selected sites in the town of Zvolen under different weather conditions in the years 2013-2016

Source: authors' measurements 
by 2.2-4.7 lux. These greater values than the threshold (1 to 2 times) were caused by the replacement of public lighting in some parts of the housing estate. In the case of some measurements, mostly under cloudy and rainy weather conditions, the illumination values ranged from 16 to 24 lux, which greatly exceeded the threshold values. Despite the most appropriate type of lamps with flat diffusers, the high luminance of LED bulbs resulted in a threshold value that was exceeded 8-12 times. Similar situations were observed also in the town centre, where the light pollution most significantly affected tree species planted in rows. It would be preferable to use lights with shades installed horizontally or with minimum inclination directed at target spots.

The basic statistical characteristics of light intensity are presented in Table 3 . We found that the smallest adverse impact on the surrounding environment was at site 1 with the lowest values of illumination. The greatest variation $(\mathrm{CV}=35.4 \%)$ resulted from the change of lights at some streets during the last two years. The worst situation was in the town centre, where the lowest variation of $12.5 \%$ was due to the same type of lights during the whole analysed period. The highest light pollution resulted from the light sources with spherical diffusers and a greater number of light elements at the pedestrian zone.

\subsection{Light pollution and tree species}

We observed adverse impacts of light on the phenological phases of tree species. More specifically, we examined the impact of light on the development of autumn phenological phases on the tree crowns situated directly under the light sources and further from the light sources. Different tree species were the subject of observations. The most common were individuals of the staghorn sumac (Rhus typhina L.) and the sycamore maple (Acer pseudoplatanus L.). We observed the onset and the duration of individual phenological phases on five (5) individuals of each species. Intensive night illumination caused the delay of the autumn phenological phase of leaf colouring on the lit crown part of the staghorn sumac (Rhus typhina L.) (see Fig. 2). The shift in the phenological phase was observed under all types of lights installed in the town of Zvolen.

Table 4 presents an overview of the basic statistical characteristics of the onset of autumn phenological phases. It is clear from these values that the dry and warm summer in 2015 caused the earliest onset of phenophases in both species, while the latest onset of most of the phenophases in 2014 indicates more favourable conditions for these species in the summer. Previous research has also been confirmed in light pollution conditions but with lower variability, as shown by lower variation coefficients. The statistical significance of the differences has not been confirmed for such a short period of time.

At the crown part situated close to the light source, the average onset of leaf colouring of the sycamore (Acer pseudoplatanus L.) was delayed by 13 to 22 days, and of the staghorn sumac (Rhus typhina L.) by 16 to 18 days (Fig. 3 ). The differences in the leaf fall between the lit and the unlit crown parts were from 13 to 20 days, depending on the tree

\begin{tabular}{ccccccc}
\hline Site & $\overline{\mathbf{x}}$ & Max & Min & SD & CV & SEM \\
\hline 1 & 2.9 & 10.2 & 0.8 & 1.0 & 35.4 & 0.27 \\
2 & 6.5 & 16.3 & 1.8 & 1.5 & 23.1 & 0.40 \\
3 & 9.6 & 24.3 & 3.2 & 1.2 & 12.5 & 0.32 \\
\hline
\end{tabular}

Tab. 3: Statistical characteristics of light pollution intensity in the sites of Zvolen in the period from 2013 to 2016 ; represented are: arithmetic mean $(\bar{x})$, largest (Max) and smallest (Min) value, standard deviation (SD), coefficient of variation (CV) and standard error of the mean (SEM). Source: authors' calculation

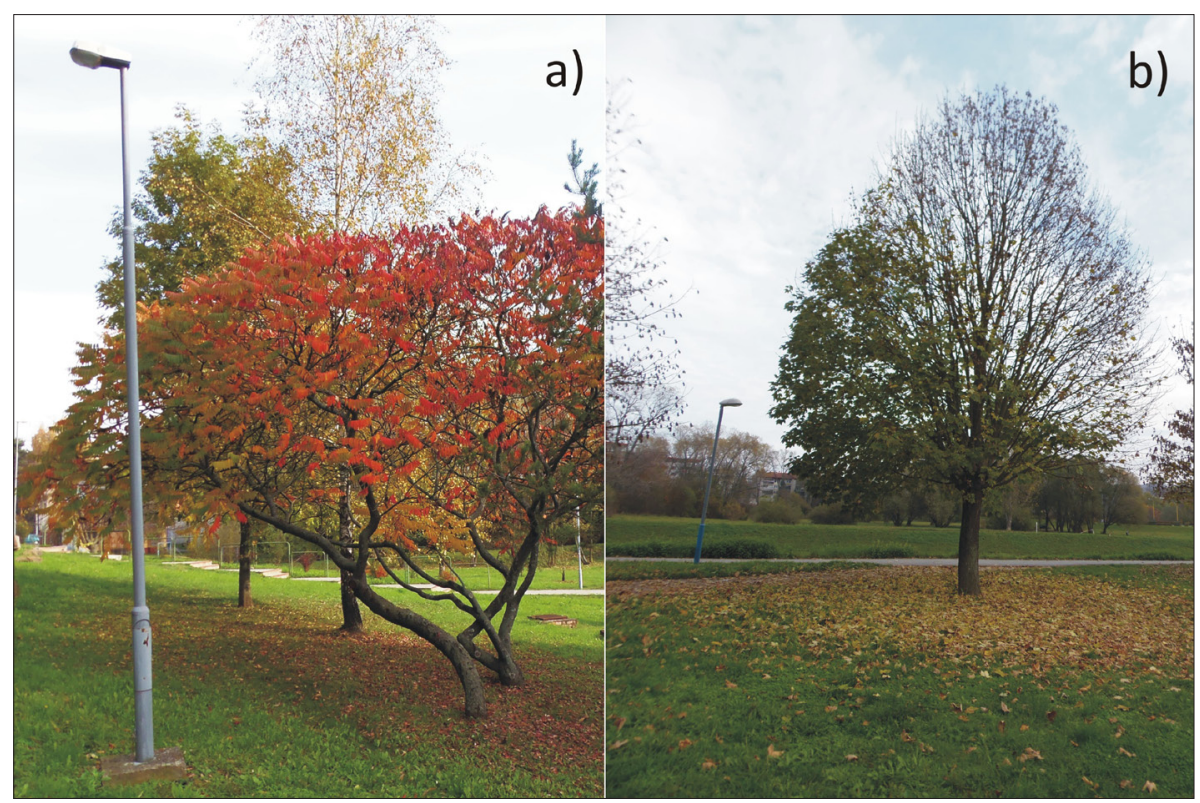

Fig. 2: (a) Difference in the onset of leaf colouring phenological phase of the staghorn sumac (Rhus typhina L.) at site 3, and (b) Sycamore maple (Acer pseudoplatanus L.) at site 1. The light source (left) caused the delay of the leaf fall phenological phase. Photos: M. Tuhárska 


\begin{tabular}{|c|c|c|c|c|c|c|}
\hline \multirow[t]{2}{*}{ Phenological Phases } & \multicolumn{3}{|c|}{ Lighted part } & \multicolumn{3}{|c|}{ Non-lighted part } \\
\hline & Min & $\operatorname{Max}$ & $\mathrm{CV}$ & Min & $\operatorname{Max}$ & $\mathrm{CV}$ \\
\hline \multicolumn{7}{|l|}{ Rhus typhina } \\
\hline LC $10 \%$ & 3.10 .2015 & 5.11 .2014 & 1.26 & 25.9.2015 & 20.10 .2014 & 1.38 \\
\hline LC $50 \%$ & 14.10 .2015 & 15.11 .2014 & 1.22 & 6.10 .2015 & 31.10 .2014 & 1.30 \\
\hline LF $10 \%$ & 26.10 .2015 & 20.11.2014 & 1.31 & 18.10 .2015 & 6.11 .2013 & 1.45 \\
\hline \multicolumn{7}{|l|}{ Acer pseudoplatanus } \\
\hline LC $10 \%$ & 4.10 .2015 & 26.10 .2014 & 1.31 & 15.9 .2015 & 8.10 .2014 & 1.42 \\
\hline LC $50 \%$ & 13.10 .2015 & 8.11 .2013 & 1.25 & 25.9.2015 & 16.10 .2014 & 1.34 \\
\hline LF $10 \%$ & 16.10 .2015 & 10.11 .2014 & 1.38 & 3.10 .2015 & 24.10 .2014 & 1.47 \\
\hline
\end{tabular}

Tab. 4: Statistical characteristics of autumn phenological phases tree species during the period 2013-2015 (largest (Max), smallest (Min) values, coefficient of variation (CV))

Source: authors' calculation

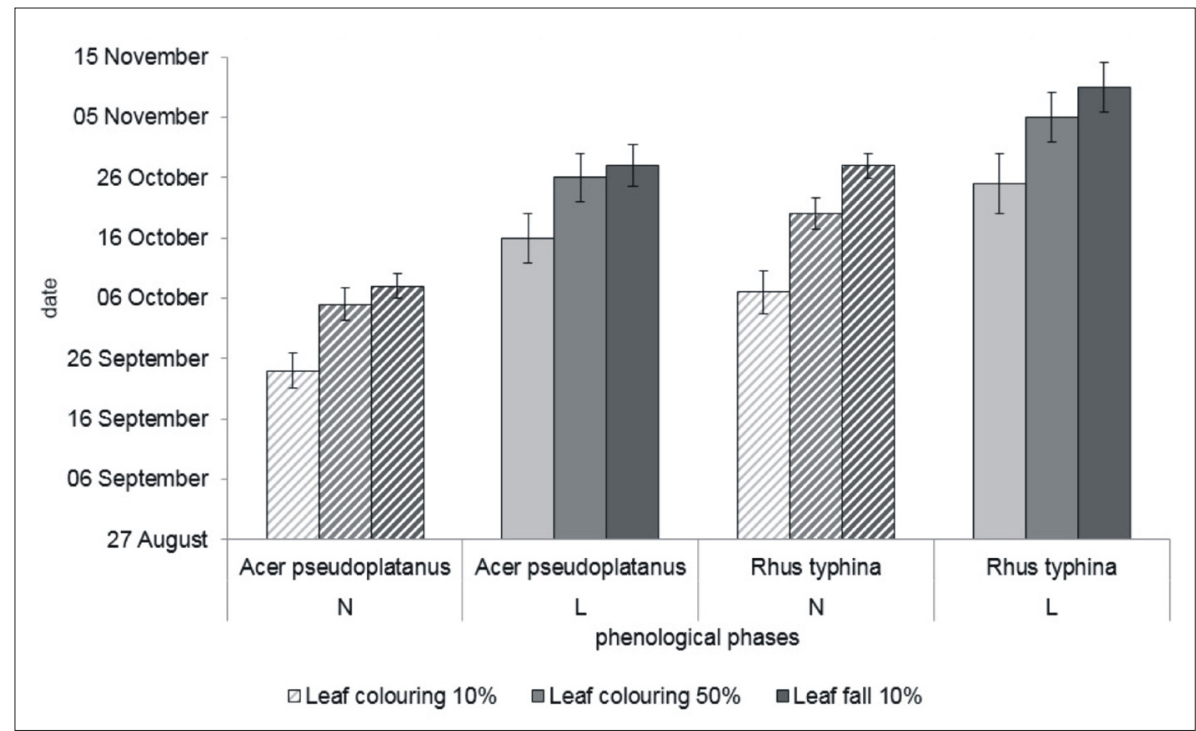

Fig. 3: Average onset ( \pm SEM - standard error of the mean) of three autumn phenological phases of the sycamore maple (Acer pseudoplatanus L.) and the staghorn sumac (Rhus typhina L.) in Zvolen from the years 2013 to 2015; where: non-lighted part ( $N$ - hatched bars) and lighted part ( $L$ - filled bars)

Source: authors' calculation

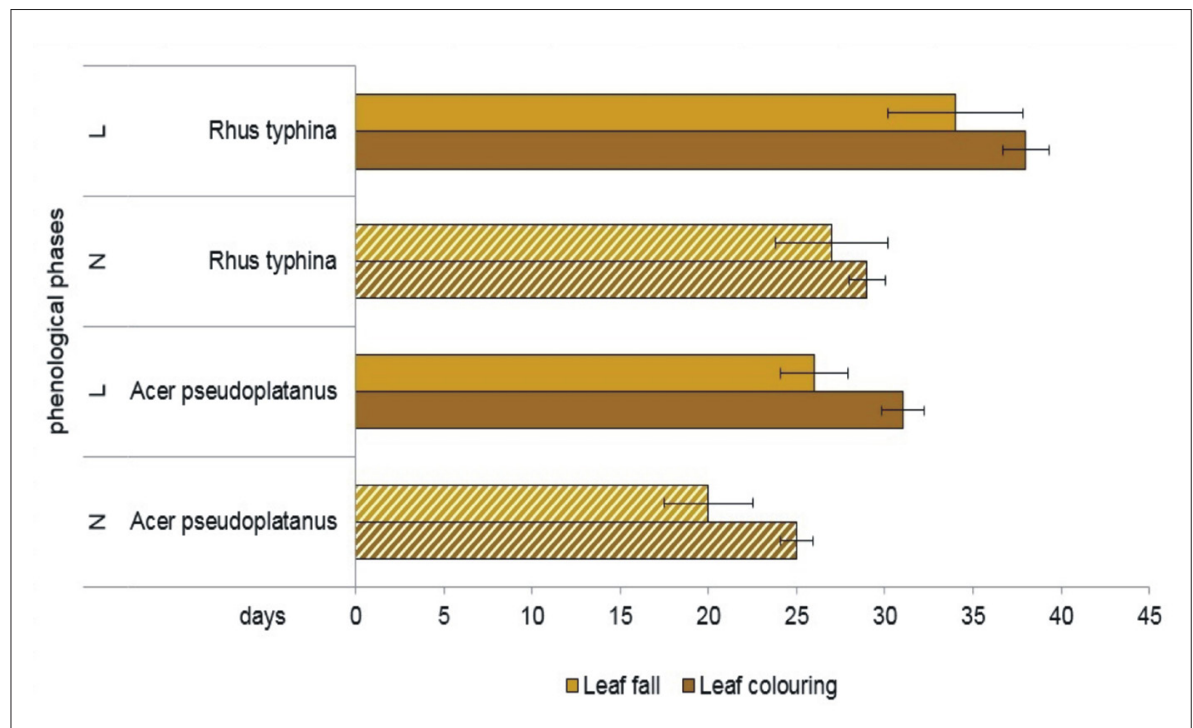

Fig. 4: Average length ( \pm SEM Quercus robur L., Fraxinus excelsior L. - standard error of the mean) of two autumn phenological phases of the sycamore maple (Acer pseudoplatanus L.) and the staghorn sumac (Rhus typhina L.) in Zvolen from the years 2013 to 2015; where: non-lighted part ( $\mathrm{N}$ - hatched bars) and lighted part (L-filled bars) Source: authors' calculation 
species. Figure 4 shows the temporal shift of the phenological phases equal to the length of two phases (from leafing to leaf fall) on the sycamore crown. Hollan (2004) found that the leaf fall of Platanus $\times$ hispanica Mill. was delayed by almost one month, i.e. to the first half of December, due to the light pollution in the central part of Brno. The differences in the intensity between the lit and the unlit part were 60 lux. The author did not state the distance of the crown from the artificial lights, hence it is not possible to compare these data with our observations.

The work of French-Constant et al. (2016) presented similar reactions also in the case of vegetative spring phenophases. Due to light pollution, leaf unfolding of Acer pseudoplatanus L., Fagus sylvatica L., Quercus robur L., Fraxinus excelsior L. started 7.5 days earlier than on the places without night lights. Chaney (2002) classified several species of Acer and Fagus genus growing in current conditions as highly sensitive to light pollution. This annually repeated phenomenon can cause the overall weakening of the tree and the reduction of its life span or worsening of its ability to withstand stress (drought, frost).

Sensitivity of other tree species (Betula pendula Roth, Negundo aceroides Moench) to artificial lighting was also observed, but due to the small number of individuals we did not evaluate the differences in the onset of their phenophases. Cathey and Campbell (1975) stated that these species belong to groups that are very sensitive to light pollution.

We also observed the duration of the phenological phases of leaf colouring and leaf fall. The phase started when its occurrence frequency was 10\% and finished at 100\% occurrence frequency. The development of the phenophase duration is presented in Figure 4. Due to lighting, leaf colouring was prolonged by 6 to 9 days on average, and leaf fall by 6 to 7 days.

Depending on radiation intensity, its wavelength and exposition, there are many possibilities to evaluate how to prevent the occurrence of light pollution or at least to eliminate its negative impact on tree species. Woody plants utilise various wavelengths for physiological processes. Photoperiodism affects production of phytochrome, which causes the absorption of red and infrared light with wavelength of 625 to 850 (Briggs, 2006). If this spectrum is emitted also by artificial sources, this kind of source can cause the day to be perceived as longer. As demonstrated on lighted leaves by longer periods with open stomas, higher sensitivity to pollution and a subsequent weakening of a tree's vitality is possible. For artificial lighting is therefore very important to use the light source with the lowest possible impact on the physiological processes in trees. To do this, Chaneys (2002) recommends using lamps with mercury vapour and metal halide, fluorescent lamps. French-Constant et al. (2016) state that the harmfulness of light might be decreased by reduced colour, the temperature of the lighting, along with limited planting of woody plants, mainly bushes, under the light source. In our case, the suitable solution would be fluorescent or discharge tubes with lower intensity of radiation and with orientation out of treetops. Another possibility is the installation of timeswitches reacting to movement, or lamps with flat diffusor lighting towards the ground.

Cathey and Campbell (1975) have recommend switching off light sources throughout the first part of the evening for 2 to 4 hours. The woody plants thus can retain their natural biorhythm. For the planting of woody plants near light sources, it would be preferable to use less sensitive coniferous species or to use places out of the reach of lighting. Future research needs to be focused on the dependence of the phenological responses of the trees to various wavelengths of light.

\section{Conclusions}

At higher air humidity and cloudy weather, the average intensity of light pollution was 1 to 2 times greater than under clear sky conditions at all sites. According to the standard valid for Slovakia, after 10:00 pm. the highest permissible value of disturbing light is 5 lux, and in housing suburbs it is 2 lux. In the years 2015 and 2016, this standard was exceeded by 2.2 to 4.7 lux due to the replacement of the public lighting at some streets of the housing estates. For some measurements, usually under cloudy weather conditions, maximum values of the measured light were between 16 and 24 lux, which greatly exceeded the threshold values. The light pollution affected the biorhythm of Acer pseudoplatanus L. and Rhus typhina L. It caused the delay of the onset of autumn vegetative phenological phases at crown parts under the lights by 13 to 22 days on average. Due to the lighting, the duration of leaf colouring was prolonged by 6 to 9 days, and the duration of leaf fall by 6 to 7 days. These tree species belong to groups that are highly sensitive to light pollution. These findings should be taken into account by planning authorities.

\section{Acknowledgement}

This work was accomplished as a part of VEGA projects No. 1/0463/14 and 1/0589/15. This work was supported by the Slovak Research and Development Agency under contracts Nos. APVV-15-0425 and APVV-15-0497. The authors would like to thank the anonymous reviewers for their helpful and constructive comments that greatly contributed to improving the paper. They would also like to thank the Editors for their comments and support during the review process.

\section{References:}

ASTOLFI, S., MARIANELLO, C., GREGO, S., BELLAROSA, R. (2012): Preliminary investigation of LED lighting as growth light for seedlings from different tree species in growth chambers. Notulae Botanicae Horti Agrobotanici Cluj-Napoca, 40(2): 31-38.

BEDNÁŘOVÁ, E., SLOVÍKOVÁ, K., TRUPAROVÁ, S., MERKLOVÁ, L. (2013): Results of a phenological study of the European larch (Larix decidua Mill.) growing in a mixed stand. Acta Universitatis Agriculturae et Silviculturae Mendelianae Brunensis, 61(5): 1239-1246.

BELÁČEK, B., BEBEJ, J. (2013): Poloha a geomorfologické pomery. Geologické pomery a geologický vývoj Zvolenskej kotliny. In: Bebej, J. [ed.]: Príroda, Monografia mesta Zvolen (pp. 12-19). Zvolen, Mestský úrad Zvolen.

BENNIE, J., DAVIES, T. W., CRUSE, D., GASTON, K. J. (2016): Ecological effects of artificial light at night on wild plants. Journal of Ecology, 104(3): 611-620.

BENNIE，J., DAVIES，T. W., DUFFY, J. P., INGER，R., GASTON, K. J. (2014): Contrasting trends in light pollution across Europe based on satellite observed night time lights. Scientific Reports, 4: 3789.

BRIGGS, W. R. (2006): Physiology of Plant Responses to Artificial Lighting. In: Rich, C., Longcore, T. [eds.]: 
Ecological consequences of artificial night lighting (pp. 389-411), Washington, Island Press.

BUJALSKÝ, L., BŘEZINA, S., MATĚJÍČEK, L., FROUZ, J. (2014): Light pollution caused by artificial illumination on downhill ski tracks in the Krkonoše Mts National park. Opera Corcontica, 51: 109-124.

BULA, R.J., MORROW, R. C., TIBBITTS, T. W., BARTA, D. J., IGNATIUS, R. W., MARTIN, T. S. (1991): Light emitting diodes as a radiation source for plants. HortScience, 26: 203-205.

CASHAMORE, A. R. (2003): Cryptochromes: Enabling Plants and Animals to Determine Circadian Time. Cell, 114: 537-543.

CATHEY, H. M., CAMPBELL, L. E. (1975): Security lighting and its impact on the landscape. Journal of Arboriculture, 1(10): 181-187.

CHANEY, W. (2002): Does night lighting harm trees? Circular FNR-FAQ-17, Department of Forestry and Natural Resources, Purdue University [online]. [cit. 13.11.2016]. Available at: https://www.extension.purdue. edu/extmedia/fnr/fnr-faq-17.pdf

CHUCHMA, F., STřEDOVÁ, H., STŘEDA, T. (2016): Bioindication of climate development on the basis of long-term phenological observation. In: MendelNet 2016 (pp. 380-383), Brno, Mendel University.

Commission Regulation (EC): No.245/2009 [online]. [cit.16.8.2016]. Available at: http:/ eurlex.europa.eu/LexUriServ/LexUriServ. do?uri=OJ:L:2009:076:0017:0044:CS:pdf

DA SILVA, A., VALCU, M., KEMPENAERS, B. (2015): Light pollution alters the phenology of dawn and dusk singing in common European songbirds. Philosophical Transactions of the Royal Society B-Biological Sciences, 370(1667): 20140126.

ELLEFSEN, R. (1991): Mapping and measuring buildings in the canopy boundary layer in the U.S. cities. Energy and Buildings, 15-16(3-4): 1025-1046.

FRENCH-CONSTANT, R., YEATES, R. S., BENNIE, J., ECONOMOU, T., HODGSON, D., SPALDING. A., McGREGOR. P. (2016): Light pollution is associated with earlier tree budburst across the United Kingdom. Proceedings of the Royal Society B-Biological Sciences, 283(1833): 20160813.

GASTON, K. J., BENNIE, J., DAVIES, T. V., HOPKINS, J. (2013): The ecological impacts of night time light pollution: a mechanistic appraisal. Biological Reviews, 88(4): 912-927.

GELETIČ, J., VYSOUDIL, M. (2012): Analysis of surface temperatures in urban and suburban landscapes from satellite thermal images: a case study of Olomouc and its environs, Czech Republic. Moravian Geographical Reports, 20(1): 2-15.

HÁJKOVÁ, L., KOŽNAROVÁ, V., SULOVSKÁ, S., RICHTEROVÁ, D. (2012): The temporal and spatial variability of phenological phases of the Norway spruce (Picea abies (L.) Karsten) in the Czech Republic. Folia Oecologica, 39(1): 10-17.

HÖLKER, F., MOSS, T., GRIEFAHN, B., KLOAS, W., VOIGT, C. C., HENCKEL, D., HÄNEL, A., KAPPELER, P. M., VÖLKER, S., SCHWOPE, A., FRANKE, S.,
UHRLANDT, D., FISCHER, J., KLENKE, R., WOLTER, C., TOCKNER, K. (2010): The dark side of light: a transdisciplinary research agenda for light pollution policy. Ecology and Society, 15(4): 13.

HOLLAN, J. (2004): Mapování světelného znečištění a negativní vlivy osvětlování umělým světlem na živou přírodu na území České republiky. Výzkumná správa. Brno, Masarykova univerzita.

HREŠKO, J., PETROVIČ, F., MIŠOVIČOVÁ, R. (2015): Mountain landscape archetypes of the Western Carpathians (Slovakia). Biodiversity and Conservation, 24(13): 3269-3283.

IDA (2013): International Dark-Sky Asociation. [online] [cit.16.8.2016]. Available at: http://www.darksky.org

JOHNSTON, T. J., PENDLETON, J. W., PETERS, D. B., HICKS, D. R. (1969): Influence of Supplemental Light on Apparent Photosynthesis, Yield, and Yield Components of Soybeans (Glycine max L.) 1. Crop Science, 9: 577-581.

KLIMEŠOVÁ, J., STŘEDA, T. (2016): Agrometeorological and biological aspects of maize transpiration. In: Brzezina et al. [eds.]: Mendel and Bioclimatology (pp. 150-156), Mendel University in Brno, Brno.

KOLEKTÍV (1984): Návod pre fenologické pozorovanie lesných rastlín. Bratislava, Slovak Hydrometeorological Institute.

KRUK, B., INSAUSTI, P., RAZUL, A., BENECH-ARNOLD, R. (2006): Light and thermal environments as modified by a wheat crop: effects on weed seed germination. Journal of Applied Ecology, 43: 227-236.

KYBA, C. C. M., RUHTZ, T., FISCHER, J. (2011): Cloud Coverage Acts as an Amplifier for Ecological Light Pollution in Urban Ecosystems. PLoS ONE, 6(3): e17307.

KYBA， C. C. M., KUESTER, T., DE MIGUEL， A. S., BAUGH, K., JECHOW, A., HÖLKER, F., BENNIE, J., ELVIDGE, C. D., GASTON, K. J., GUANTER, L. (2017): Artificially Lit Surface of Earth at Night Increasing in Radiance and Extent. Science Advances, 3(11): e1701528.

LAPIN, M., FAŠKO, P., MELO, M., ŠŤASTNÝ, P., TOMLAIN, J. (2002): Climatic regions. Landscape atlas of the Slovak Republic. Primary landscape structure. 1st ed. Ministry of Environment of the Slovak Republic Bratislava, Slovak Environmental Agency Banská Bystrica.

LEHNERT, M., GELETIČ, J., HUSÁK, J., VYSOUDIL, M. (2015): Urban field classification by "local climate zones" in a medium-sized Central European city: the case of Olomouc (Czech Republic). Theoretical and Applied Climatology, 122(3-4): 531-541.

LONGCORE, T., RICH, C. (2004): Ecological light pollution. Frontiers in Ecology and the Environment, 2(4): 191-198.

McLAUREN, J.S., SMITH, H. (1978): The function of phytochrome in the natural environment. V. Phytochrome control of the growth and development of Rumex obtusifolius under simulated canopy light environments. Plant, Cell and Environment, 1: 61-67.

OKAMOTO, K., YANAGI, T., KONDO, S. (1997): Growth and morphogenesis of lettuce seedlings raised under different combinations of red and blue light Available at: http:// www.actahort.org/books/435/435_14.htm 
OKE, T. R. (2006): Initial guidance to obtain representative meteorological observations at urban sites. Instruments and Observing Methods, Report No. 81. Geneva, WMO.

POKLADNÍKOVÁ, H., FUKALOVÁ, P., ROŽNOVSKÝ, J., STŘEDA, T. (2009): Specifics of temperature extremes in the conditions of the urban climate. In: Pribullová and Bičárová [eds.]: Sustainable Development and Bioclimate (pp. 217-218), Stará Lesna, Geophysical Institute of the SAS.

RICH, C., LONGCORE, T. (2006): Ecological consequences of artificial night lighting. Washington, Island Press.

RIEGEL, K. W. (1973): Light pollution: outdoor lighting is a growing threat to astronomy. Science, 179: 1285-1291.

SABZALIAN, M. R., HEYDARIZADEH, P., MORTEZA, Z., BOROOMAND, A., AGHAROKH, M. (2014): High performance of vegetables, flowers, and medical plants in a red-blue incubator for indoor plant production. Agronomy for Suitable Development, 34(4): 879-886.

SAMACH, A., GOVER, A. (2001). Photoperiodism: The Consistent Use of Constans. Current Biology, 11: 651-654.

SEARLE, I., COUPLAND, G. (2004): Induction of Flowering by Seasonal Changes in Photoperiod. The Embo Journal, 23: $1217-1222$

SOLANO LAMPHAR, H. A., KOCIFAJ, M. (2013): Light pollution in ultraviolet and visible spectrum: Effect on different visual perceptions. Plos One, 8(2): e56563.

SONG, Y. H., SMITH, R.W., TO, B. J., MILLAR, A. J., IMAIZUMI, T. (2012): FKF1 Conveys Timing Information for CONSTANS Stabilization in Photoperiodic Flowering. Science, 336: 1045-1049.

STEHNOVÁ, E., STŘEDOVÁ, H. (2016): Fenologie řepy cukrové $\mathrm{v}$ kontextu rizika vodní eroze. Listy cukrovarnické a řepařské. 132(12): 380-386.

STEWART, I. D., OKE, T. R. (2012): Local climate zones for urban temperature studies. Bulletin of American Meteorological Society, 93(12): 1879-1900.

STN EN 12464-2 (2014): Svetlo a osvetlenie. Osvetlenie pracovísk. Čast’ 2: Vonkajšie pracoviská. Available at: http://www.svetelneznecistenie.sk/aktualne/135legislativa-na-slovensku.html?start $=2$
STŘEDOVÁ, H., STŘEDA, T., LITSCHMANN, T. (2015): Smart tools of urban climate evaluation for smart spatial planning. Moravian Geographical Reports, 23(3): 47-57.

STŘELCOVÁ, K. (2013): Klimatické pomery vo Zvolene a okolí. In: Bebej, J. [ed.]: Príroda, Monografia mesta Zvolen (pp. 22-35), Zvolen, Mestský úrad Zvolen.

TAKEMIYA, A., INONE, S-I., DOI, M., KINOSHITA, T., SHIMAZAKI, K-I. (2005): Phototropins Promote Plant Growth in Response to Blue Light in Low Light Environments. The Plant Cell, 17: 1120-1127.

TUHÁRSKA, M., KRNÁČOVÁ, D., ŠKVARENINOVÁ, J., HRÍBIK, M. (2016): Intensity of light pollution and its impact on phenological phases of trees. In: Brzezina, J. et al. [eds.]: Mendel and Bioclimatology (pp. 398-403), Brno, Mendel University.

VERHEIJEN, F. J. (1985): Photopollution: artificial light optic spatial control systems fail to cope with. Incidents, causations, remedies. Experimental Biology, 44(1): 1-18.

Vyhláška Ministerstva zdravotníctva Slovenskej republiky č. 539/2007 Z. z. o podrobnostiach o limitných hodnotách optického žiarenia a požiadavkách na objektivizáciu optického žiarenia v životnom prostredí. [online]. [cit.16.8.2016]. Available at: http://www.uvzsr.sk/docs/ leg/539 2007opticke ziarenie.pdf

VYSOUDIL, M., LEHNERT, M., KLADIVO, P. (2016): Heat Stress in the Urban and Suburban Landscape and its Spatial Differentiation through the Example of a Medium-Sized City. Dela, 46: 163-182.

WHITE, A. G. (1974): Excessive light as a form of urbancreated pollution: a selected bibliography. Monticello, Illinois, Council of Planning Librarians.

YEH, N., CHUNG, J.P. (2009): High-brightness LEDs: energy efficient lighting sources and their potential in indoor plant cultivation. Renewable and Sustainable Energy Reviews, 13(8): 2175-2180.

\section{Please cite this article as:}

ŠKVARENINOVÁ, J., TUHÁRSKA, M., ŠKVARENINA, J., BABÁlOVÁ, D., SLOBODNÍKOVÁ, L., SLOBODNÍK, B., STŘEDOVÁ, H., MINĎAŠ, J. (2017): Effects of light pollution on tree phenology in the urban environment. Moravian Geographical Reports, 25(4): 282-290. Doi: 10.1515/mgr-2017-0024. 